\title{
Tutor ICT Skills and the Realisation of Kenya's Vision 2030
}

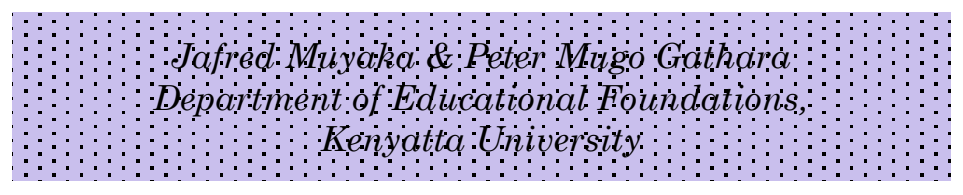

\section{Abstract}

The Kenya Vision 2030 identifies science, technology and innovation as key drivers in creating wealth, social welfare and international competitiveness. In recognition of the role of technology in achieving Vision 2030, the government pledged to strengthen technical capabilities by emphasising technological learning at all levels. The vision affirmed that it is only through an educated and skilled manpower that Kenya will be able to create, share and utilise knowledge well. To produce a workforce capable of fitting into the knowledge driven society, training of teachers in Primary Teachers Colleges was to integrate Information and Communication Technologies (ICTs) in teaching and learning. The government carefully prepared ICT policies to guide the use of ICTs in teaching and learning as a proper way of imparting in teacher trainees the skills needed for preparing learners with the right training. Among the policies was providing extensive training to tutors on use of ICTs in teaching and learning. The study analysed the implementation of this policy in Primary Teachers Colleges. The analysis sought 
to find out whether and what gaps exist between the stated government policy designed to guide use of ICTs in teaching and learning and the actual practice during the implementation process. The study sites were four PTCs in Kenya offering certificate courses commonly known as P1 colleges. These were three public PTCs and one private college targeting college heads, deans of curriculum, tutors, students and Ministry of Education officials. The study applied multiple case study design in soliciting views, perceptions, opinions and experiences regarding implementation of government ICT policies. A combination of research instruments were used in collecting the data. These included:- questionnaires, interviews and observation schedules. The data was analysed both qualitatively and quantitatively using SPSS. The study findings established that there were a number of inconsistencies in the implementation of government policies on use of ICTs in teaching and learning and the actual practice during the implementation process. Although the policy required that lecturers at PTCs were to attend ICT in-service training to integrate ICT in classroom teaching, $53.8 \%$ of the teaching staff had not attended any in-service training on use of ICT in teaching and learning. The study concludes that the identified inconsistencies in the use of ICT skills of tutors had impacted negatively on the preparation of primary teachers with competencies in ICT use, hence undermining the realisation of Vision 2030. Therefore the study recommends establishment of partnership between the government, private sector and the PTCs to equip the tutors with the necessary and relevant ICT training to allow integration of ICT in teaching and learning. 


\section{Introduction}

Investment in Information, Communication and Technology (ICT) for education has grown steadily over the past decade in developing countries following similar growth in developed countries a decade earlier. The power of ICTs as enablers of change for both good as well as bad is undeniable (Trucano, 2013a). The world over, it is widely acknowledged that it will be impossible for many countries to meet many of the education related Millennium Development Goals (MDGs) and Education for All (EFA) goals without harnessing the potentials of ICTs.

The MDG number two together with EFA goal two both advocate for the achievement of Universal Primary Education (UPE) of good quality by the year 2015. Researchers observe that these goals can effectively be enhanced by ICTs together with the EFA goal number 3 and 5 that address learning needs of all young people and adults where the emphasis is on accessing appropriate learning and life skill programmes. The need for ICTs in education was further reinforced in the Education for All (EFA) follow up meeting held in Dakar, Senegal in 2000, where item 69 emphasised the need to harness ICTs to support EFA goals. It was agreed that since 
ICTs provide the potential for knowledge dissemination, and effective learning strategies, it should be used extensively in the training of teachers.

The vital roles played by ICTs that go beyond provision of quality education to its role as an impetus for economic development have led to mainstreaming of ICTs in many education systems of the world. To enforce the practice and ensure uniformity in its use, countries have developed policies to guide its use especially for teaching and learning. For instance, the United States of America (USA) has a national ICT policy for education which outlines the objectives, strategies, and indicators for its use. Standards for teachers and technology use are set with specifications of performance indicators for assessing teachers' abilities in classrooms. Pre-service programmes have incorporated technology in their programmes to enhance acquisition of ICT skills by teacher trainees. Computer programmes and software are developed to aid teaching with an established education rate (e-rate) that connects schools to internet services at affordable prices. The country has established the International Society for Technology in Education (ISTE), a central body which sets the standards and provides consistency in use of technology in education. 
Brazil's ICT policy is another good case where ICT has been used as an avenue to increase access to quality education (Gutterman et al., 2009). The country has a national policy for ICT headed by a Secretariat for Distance Education. The national ICT policy makes it a requirement for institutions to integrate technology in education. Furthermore, they have developed centres to train laboratory coordinators and teachers to ensure long term success. The country allows funding for teachers' professional development for proficiency courses to keep abreast of technology use in education (Gutterman, et al., 2009).

In August 2004, an inter-ministerial conference on ICT and education for African countries was held in Abuja (Nigeria) under the theme, 'Integration of Computer Technology in Education.' The resolution of the conference was to train more teachers with competencies in integration of ICTs in education. Its key recommendation was that African countries should formulate national ICT policies to guide the training of ICT teachers and review the teacher training programs by fusing ICTs.

Evolution of computer technology in Kenyan education can be traced back to the late 1970's 
(Hennessy, Onguko, Harrison, Ang'ondi, Namalefe, Naseem and Wamakote, 2010) with policy formulation in the late 1980s. However, this process remained incomplete until 2000 (Nduati \& Bowman, 2005). The recommendations in the Abuja conference coupled with other local and international efforts led to the introduction of ICT in Kenyan education. The contents of ICT was taught as a subject commonly known as computer in primary and secondary schools. In higher education, it was referred to as Information Technology in middle level colleges and Computer Science in universities (Ministry of Education, 2006 \& TIVET, 2011). However, it is important to observe that Kenyan universities had introduced computer related courses much earlier before the government officially introduced it in primary, secondary and middle level colleges. The Ministry of Education (MoE) has since then taken an active role in teaching of ICT in Kenyan institutions.

Kenya's Vision 2030 was developed in 2005 following a recommendation by the National Economic and Social Council to the government of Kenya to draft a long-term vision to guide its development up to the year 2030. The Vision aims to drive Kenya into a middle-income nation by the year 2030. The 
Vision is structured on three main pillars: economic, social and political governance, under which other projects and priority programmes have been drawn. Information and Communication Technology (ICT) is one of the sector plans drawn from the three pillars to steer the country towards economic empowerment. ICT is drafted as a sector on its own right and as an enabler of all other sectors (Ministry of Labour, 2012). As an enabler for other sectors, it is seen in the context of its contribution to national development through creation of human resources. The country intends to create a globally competitive and adaptive human resource base to meet the requirements of a rapidly industrialised economy.

The ICT sector is seen to play an essential role in graduating the country into an information and knowledge economy. It is expected to promote and develop the much needed human capital for the ICT dependent sectors (Condie et al., 2007). This has seen a lot of efforts from the Government to improve teacher training institutions to equip teachers with relevant and appropriate skills in use of ICT in teaching and learning. An area seen as likely to reinforce use of ICTs in teaching and learning in PTCs is the ICT skills of tutors. The tu- 
tors are expected to have expertise in use of technologies in teaching, be prepared to utilize software to teach the curriculum, apply ICT appropriate teaching methodologies and ability to employ appropriate assessment practices when teaching with technologies. Consequently, preparation of tutors on their roles in a fast changing society becomes unavoidable.

\section{The Role of Competent ICT Tutors in Achiev- ing Vision 2030}

The role of tutors in achieving Vision 2030 cannot be overemphasized. Ideally, teachers should have the ability to operate technologies such as computers, to utilise software to teach the curriculum, to apply current instructional principles, and to employ appropriate assessment practices when teaching with technologies. Consequently, it is desirable that college and school administrators should have an understanding of the role played by ICT in education and the relevance of National ICT Policy in achieving Vision 2030. This ensures that they are in the forefront of investing in use of ICT in teaching and learning and enforcing institutional policy frameworks for integration of ICTs in education (Hennessy et al., 2010). 
For appropriate use of ICTs, then, teachers at all levels will be required to be in an environment that allows for maximum use of technology when working. For instance, there is a need to provide them with their own ICT infrastructure since such access rapidly improves their competence and confidence when utilising technologies. Ensuring teachers have access to computers at home comes with another advantage of finding non contact time to prepare for contact teaching. The confidence in using computers and other technologies aid instructors to search for, retrieve, prepare, and present educational materials using technologies. This calls for an understanding of the education context on the part of the instructors to be able to tell when the use of technology is needed and when it is not required. The knowledge and skills on how to use technology as a tool to support learner-centered teaching, continuous assessment, and other forms of interactive learning are imperative. This might demand an ICT qualification for teachers involved in teaching and learning if the right skills and competence for use of ICTs in achieving Vision 2030 are to be met.

The question of how we prepare our tutors in training institutions to take up their roles in a 
fast changing society is therefore timely. It is now common knowledge that the (right) skills that we invest in the teachers get replicated while they teach. Since teachers remain important in meeting Vision 2030, the question of who prepares them becomes not only important but worthy of investigation. While supporting the role of teachers in implementing anything new in schools, Little et al. (1994) argued that for change geared to meet the learning needs for all to succeed, it must first find expression in the teaching institutions. It is in line with this that UNESCO (2008) report on ICT identified the training of teachers with competence as key in the use of ICTs in schools. Generally, use of ICTs in education not only demands for better qualified applicants but also well qualified staff capable of using ICTs in education delivery. This had earlier been reiterated by UNESCO (2002) when they pointed out that there is need for a generation of new leaders who are able to utilise the new devices to enhance their productivity and decision making. The intention should not be to change the college leaders and tutors but involve them in relevant and adequate in-servicing training on the use of technology in education. This is necessary since without effective and supportive leadership, changes in teaching and learning process through 
technology are not likely to occur (Hennessy et al., 2010). Qualified teachers are often seen as a catalyst in the introduction and effective use of technology in institutions. They have specific roles that cannot be delegated if ICTs have to be tapped fully to maximise their potentials in the provision of relevant education. While tutors will require technicians to fix technical aspects of ICTs, Farrell (2007) observes that tutors will be required to know how to exploit its proper application to maximise its potentials in teaching.

For Kenya to achieve Vision 2030, learning institutions like PTCs have been given a critical role to play. The people entrusted with the responsibilities are the tutors. In a study to evaluate their ICT skills and how these skills affect their contribution to training a new generation of teachers to steer the country to Vision 2030, the researchers evaluated the implementation process of ICT policies in four (4) Kenyan Primary Teachers Colleges.

\section{Research Design and Methodology}




\section{Research Design}

The study utilised a descriptive multiple case study design of the selected Primary Teachers Colleges (PTCs) in Kenya in analysing the ICT skills of tutors. A case study design is one of the qualitative research strategies that investigate a contemporary problem within its real life context (Yin, 1984: 23). The design was chosen since it allowed the researcher to present the ICT competence levels of the staff teaching at PTCs. Furthermore, the design allowed the researcher to document the tutor's opinions on the influence of ICT on the provision of relevant and appropriate education and how it affected the realisation of Vision 2030. Both qualitative and quantitative paradigms were utilised in collecting the data.

\section{Study Sites}

The study focused on PTCs offering courses leading to the Primary Teachers Education (PTE) certificate commonly referred to as 'P1'. The selection was based on a consideration that, they represent the basic teacher education institutions training majority of the primary school teachers in Kenya (MOEST, 2004). In 2011, there were thirty two (32) PTCs, twenty one (21) public and eleven 
(11) private approved by and registered by the MOE (MOE, 2011).

Out of the 32 PTCs, 4 PTCs translating to $12.5 \%$ were sampled to participate in the study. Three public PTCs were randomly sampled representing $14.3 \%$ of the 21 public PTCs. Through balloting, the following PTCs were picked: Kansas, Tatton and Thika. These are not the real names of the colleges as pseudo names were used for confidentiality purposes.

\section{Target Population}

The study targeted 3,810 students (teacher trainees), 226 tutors, 12 ICT tutors, 4 deans of curriculum, 4 deputy principals, 20 heads of departments and 4 principals within the four selected colleges as the informants.

\section{Sample and Sampling Techniques}

Members of teaching staff in the sampled colleges formed part of the informants since they were directly involved in teaching and learning process of the ICT course. A random sample of $39.8 \%$ of the teaching staff was sampled to participate in the study. Kilemi and Wamahiu (1995) note that in research, at least $10 \%$ of the population un- 
der study is an appropriate sample size for investigation. All the ICT tutors were purposively sampled as they were few and responsible for teaching ICT course, planning and setting an ICT institutional policy. This is supported by Orodho (2008) who observes that if the population is small it might be taken as the sample size. All the college heads, department and subject heads were purposefully sampled as informants to respond to a semi-structured interview. Students formed part of the informants. The researchers used purposive sampling to select 6 students (3 males and 3 females) from each institution to participate in a Focus Group Discussion (FGD).

\section{Research Findings and Discussions}

Areas that have been suggested for adequate consideration when formulating policies to guide the use of ICT with regard to the teaching staff include gender balance in the composition of the members of staff, educational qualifications, sources of staff recruitment, and in-service education. These policies have a legal framework as envisaged in Teachers Service Commission (TSC) Act Cap 212 of 1968 that provides for registration, recruitment, and deployment of teachers. 
The focus of this study was on four aspects, namely composition by gender, educational qualifications, sources of staff recruitment and in-service education.

\section{Composition of the Teaching Staff by Gender}

The policy on recruitment and deployment as stipulated in the new constitution demands gender parity in the teaching staff. Analysis of documents and statistical data available in the official records established that PTCs had well trained men and women tutors as indicated in Figure 1. The figure indicates that Mwembe TTC had the highest gender disparity in favour of men. The teaching staff comprised of 29 (82.9\%) men and 6 women (17.1\%). Furthermore, Figure 1 shows that all the three public teachers training colleges were consistent with the policy on gender composition of the teaching staff. Glaring gender disparity in private colleges (Mwembe) meant lack of female role models in use of ICTs in teaching and learning for female teacher trainees. Vision 2030 places women at the centre of the socio-economic transformation necessary for moving Kenya into a middle income country. 
Figure 1: Gender Composition of Teaching Staff at PTCs

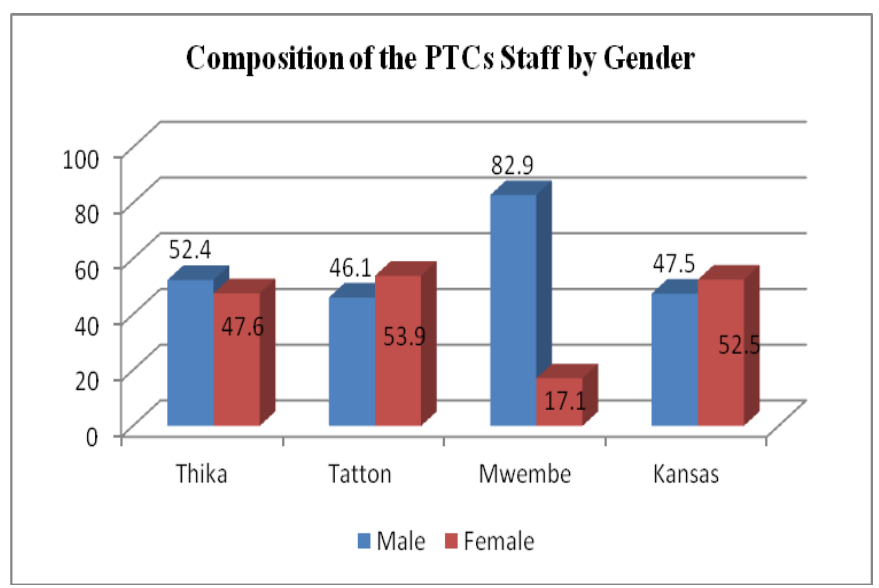

The educational qualifications of lecturers in PTCs varied from certificate to master degrees as shown in Table 1.

Table 1: Qualifications of Lecturers at Sampled PTCs

\begin{tabular}{|l|l|l|l|l|l|l|}
\hline $\begin{array}{l}\text { Name of } \\
\text { PTCs }\end{array}$ & \multicolumn{5}{|c|}{ Educational Qualifications } & Total \\
\hline & $\begin{array}{l}\text { Certifi- } \\
\text { cate }\end{array}$ & Diploma & Degree & $\begin{array}{l}\text { Mas- } \\
\text { ters }\end{array}$ & $\begin{array}{l}\text { Un- } \\
\text { trained }\end{array}$ & \\
\hline Thika & 0 & 4 & 14 & 6 & 0 & 24 \\
\hline Tatton & 0 & 3 & 12 & 9 & 0 & 24 \\
\hline Mwembe & 2 & 4 & 5 & 3 & 1 & 15 \\
\hline Kansas & 0 & 3 & 6 & 8 & 0 & 17 \\
\hline Total & 2 & 14 & 37 & 26 & 1 & 80 \\
\hline (\%) & 2.5 & 17.5 & 46.3 & 32.5 & 1.2 & 100 \\
\hline
\end{tabular}

Source: Files of Lecturers in the Official Records in the Institutions 
The table indicates that $96.3 \%$ of the lecturers had educational qualifications of a diploma and above. Further analysis of the group indicated that $46.3 \%$ of the lecturers had degrees and $32.5 \%$ had masters' degree in different fields. The presence of highly qualified personnel indicates provision of quality education upon which Vision 2030 is hinged. However, these efforts were watered down by the presence of $2.5 \%$ of lecturers who had certificates and $1.2 \%$ who were untrained. The $3.7 \%$ certificate holders and untrained lecturers have a weak foundation to instil in the teacher trainees the necessary skills needed to achieve Vision 2030. However, the problem of under-qualified teachers was prevalent in private TTC. The differences in educational qualifications of tutors in the public and private PTCs were wide with all the certificates and untrained teachers coming from the private college (Mwembe). This is partly because the private PTCs employ their teachers independently through Boards of Management without a well defined verification process from the MoE.

Taking into consideration the value $\mathrm{MoE}$ attaches to the institutions of higher learning that train such tutors, the researchers looked at the recruiting institutions. The policy on recruitment of 
tutors to PTCs recommends that such lecturers should be recruited within institutions of higher learning in the country (Muyaka, 2012). In addition, the policy states that any candidate from any other institution of higher learning recognised by the MoE can be recruited and deployed to teach at PTCs. These are part of Government efforts to ensure that only tutors with relevant and adequate skills acquired in accredited and recognised institutions of higher learning are deployed to teach at PTCs. This not only ensures uniformity in the education offered at pre-service training colleges but also guarantees that people who have the right skills and knowledge are entrusted to meet Vision 2030.

The data revealed that $91.3 \%$ of the lecturers had been recruited from local institutions of higher learning (post secondary institutions offering diploma in education and above). In addition, $3.7 \%$ of lecturers had been recruited from institutions of higher learning outside the country - University of Wales in United Kingdom and Poona University.

Integration of ICTs in teaching and learning alone cannot guarantee effective and quality teaching needed at PTCs to meet Vision 2030. Technology 
requires well trained personnel that can take advantage of what ICTs provide to ensure that learners are provided with relevant and adequate skills. Preparation of such personnel can only take place in institutions of higher learning with recognised standards, hence the need for a policy on recruiting institutions.

Furthermore, the study looked at the ICT preparation of TTC tutors through training for effective integration of ICTs in education. The interviews and data from questionnaires revealed that majority of the administrators and lecturers at PTCs had not attended any form of ICT training. It was only $3 / 12(25 \%)$ of the college administrators who had undergone some form of ICT training. $75 \%$ of the college administrators remain untrained on use of ICT in education.

The researcher sought to find out the ICT skills of the teaching staff. The findings revealed that only $44.2 \%$ of the teaching staff had received ICT in-service training; $55.8 \%$ had not attended any form of ICT in-service training. While many lecturers indicated their willingness to integrate ICTs in their lessons, lack of training reduced their competence and confidence levels, forcing them to adopt the traditional educational practices in teaching and 
learning. However, these traditional practices do not provide pre-service teachers with the required skills (competencies) necessary for achieving Vision 2030, hence limiting students' contribution to development of the Kenyan society.

The researcher also looked at the place of training for the $46.2 \%$ of the tutors who had indicated having had ICT in-service. The findings indicated that majority of the trained tutors (46.7\%) were trained by their individual PTCs, $23.3 \%$ by the MoE, $20 \%$ attended computer colleges outside their place of work and $10 \%$ pointed out that it was organized by Academic for Economic Development (AED), a Non Governmental Organization (NGO).

The tutors who had cited the MoE as the organizers of the ICT training were mainly from Mathematics and Science departments. They had received the training through the Strengthening Mathematics and Science in Secondary Education (SMASSE) programme. This is an initiative by the $\mathrm{MoE}$ that is funded by Japan International Cooperation Agency (JICA). It is evident that the MoE has not had an adequate training programme for PTCs tutors on ICT integration in education. 
On the length of training, the study established that it varied depending on the place of the training. For the majority of the lecturers (46.7\%) who had been trained by their respective institutions through the efforts of ICT departments, the training lasted for one to two days. On the content covered, regardless of the place of training, it seemed to be on computer literacy with little or no content on ICT integration in education. It is only in the SMASSE training for Mathematics and Science teachers that ICT integration was part of the curriculum. Tutors were not prepared on the use of ICT in teaching and learning for their respective subject areas.

The study findings further established that the age of the lecturers had an influence on use of ICT in teaching. For instance, $84.4 \%$ of lecturers under the age of 30 years rated their ICT competencies as 'good'. On the other hand, 76.3\% and $69.4 \%$ of $31-41$ and $41-50$ year-olds respectively rated their competencies as average. It was further established that $50 \%$ and $23.4 \%$ of lecturers of age 51 and above rated their ability to use computers as poor and average respectively. Those in the age bracket 51 and above also said they lacked confidence and competence on use of technologies while 
teaching. Interviews with these teachers revealed that the fear of technology (technophobia), the attitude that using ICTs would challenge them and a strong attachment to the 'status quo' in teaching, affected their efforts to learn using ICTs in teaching and learning. This is well captured by a lecturer in this category when he argues that:

Use of ICTs requires training probably young people can understand the complications that come with technologies.... and again though it might add something I think I still do what I should do well. (Male lecturer of age 51 and above)

Lack of a well planned form of training on use of ICT in the delivery of the curriculum from the MoE greatly affected the policy requirements that ICT was a tool for delivery of the educational curriculum. From the study findings, the ministry only had a training in 2006/2007 that lasted for 2 weeks. There have been no follow up trainings. Furthermore, the training offered was not mandatory. As a result, majority of teachers did not take part. The non attendance of lecturers in ICT inservice courses means lecturers who were expected to be experts in use of ICTs, and who are expected to prepare teacher trainees, lacked the necessary 
expertise to integrate ICTs in education. The limited use of ICT by lecturers as an educational tool for teaching the curriculum had a negative impact on preparing teacher trainees for Vision 2030 that depends largely on ICTs. Teacher trainees who are to use ICT in later teaching must have observed their teachers using computers. A Focus Group Discussion (FGD) on how ICT can be integrated in teaching and learning with teacher trainees cited the lack of its use when being trained as a limitation to their use in the field. This was well captured in one of the FGDs:

We have never seen tutors other than during presentation, ICT tutors and sometimes Mathematics tutors use it and ... so how do you expect us to integrate what has not been integrated during our training (One of the FGDs with teacher trainees)

Interviews in the departments exposed further differences on how ICT was integrated in teaching and learning.

The departments were not uniform. Mathematics/Science had a higher level of ICT knowledge than other departments. Apparently, all the science teachers had gone through a form of training in use of ICT in education. This is supported by the data 
from the questionnaires where $84.6 \%$ of Science teachers rated their ICT competence levels as good and above. They attributed this to SMASSE training programmes that are carried out in April and August every year. In addition, ICT integration was one of the components in SMASSE trainings. They also cited the 'Tafakari' project; a programme by Kenya Institute of Education for Mathematics and Science teachers. All the public PTCs had computers either for the SMASSE programme or the institution. However, Mwembe, a private institution, did not have computers for its Mathematics and Science teachers. On the other hand, the departments of Social Sciences and Language in all the institutions visited had not organised any training for their members. The departments cited lack of support from the Government as the ministry seems to concentrate its efforts in use of technology in education on Science and Mathematics departments.

\section{ICT Lecturers at PTCs}

The study findings revealed that the Government had deployed on average three ICT lecturers to the public PTCs to teach the ICT course. Interviews with the administration in public PTCs established that the MoE through 
TSC had recruited and deployed three ICT lecturers to the institutions. These were diploma holders from Kenya Technical Teachers Training College (KTTC). The ministry noted that they could not get highly qualified teachers to deploy to PTCs as there was no university offering an education degree course for ICT teachers in the country. The study further revealed that $16.7 \%$ of the ICT lecturers were either untrained teachers or holders of a certificate in a technology related course but training teachers. Although there was progress towards the stated government policy to have qualified staff teaching at PTCs, the presence of $16.7 \%$ of the ICT lecturers among them untrained and with qualifications lower than a diploma in education, derailed the efforts. All these teachers came from private primary teachers colleges. In one of the public institutions, two of the science teachers had voluntarily moved to teach ICT course.

In terms of workload, ICT lecturers were overloaded compared to other lecturers. On average, other lecturers had 12 lessons per week while ICT lecturers had 19. This reduced the student-teacher contact hours since the ratio of 
three ICT lecturers per institution compared to the student population was unacceptably high.

The importance of in-service courses to keep tutors abreast of new trends in any field cannot be underestimated. The researchers sought to find out how often ICT tutors attended in-service training. When ICT lecturers were asked whether they had attended any ICT inservice course in the past two years, $30 \%$ of them reported that they had not attended any since their deployment. $70 \%$ had undergone ICT inservice training following their deployment. The $30 \%$ who attended no training were obviously left out on new trends in the use of technology in teaching. The growth and development of technology and its application to teaching are known to change fast. To keep track with the changes, teachers are required to constantly attend inservice training.

\section{Recommendations}

First, the study established that the MOE had not rolled out an intensive ICT training for both private and public TTC tutors. Therefore, the study recommends that the ministry provides 
an extensive ICT training to target all tutors in both private and public PTCs. The programme should be modelled along the SMASSE approach which is provided in April and August every year. The training should include, among other things, ICT integration to ensure it goes beyond acquisition of ICT skills to include their application in classroom teaching.

Secondly, all the sampled institutions lacked an institutional policy on the use of ICT in teaching and learning. Accordingly, the study recommends that PTCs should integrate an ICT strategy into the institution's overall strategies; this includes crafting a policy to guide the use of ICTs in teaching and learning. This will ensure that ICT is planned for by teachers and becomes a key component of teaching and learning. This will elevate its status in colleges from the current situation where its use by the teaching staff is voluntary.

Lastly, the private PTCs received minimal support in use of ICTs in education. The private sector plays a vital role as a partner in training teachers. Thus, both the government and private agencies that support ICT integration in education ought to consider supporting private PTCs 
especially in the acquisition of relevant ICT infrastructure and training of tutors. The $\mathrm{MoE}$ should establish an all inclusive ICT training programme that does not exclude private colleges as has been the case.

Adoption of these recommendations will be a move in the right direction in the realisation of Vision 2030. Preparation of future teachers in PTCs will require proper training in use of ICTs in teaching and learning. 


\section{References}

Byamugisha, A., \& Ogawa, K. (2010). Universal primary education policy and quality of education in Uganda:The case of Kabale and Soroti districts. Africa Educational Research Journal, (1) pp 60-76.

Condie, R., Munro, B., Seagraves, L. \& Kenesson, S. (2007). The impact of ICT in schools: A landscape review. United Kingdom: University of StrathClyde.

Farrell, G. (2007). Survey of ICT and education in Africa: Kenya country report. Washington, DC: World Bank.

Gutterman, B., Rahman, S., Supelano, J., Laura, T., \& Mai, Y. (2009). Global Alliance for ICT and Development: New York. Accessed on 15th March 2013 from http://unpan1.un.org/intradoc/groups/public/ documents/gaid/unpan034975.pdf.

Hennessy, S., Onguko, B., Harrison, Ang'ondi, Namalefe, Naseem \& Wamakote. (2010). Developing use of ICT to enhance teaching and learning in East African schools: A review of the literature. Cambridge, UK and Dar es Salaam, Tanzania: Faculty of Education, University of Cambridge and Aga Khan University, Institute for Educational DevelopmentEastern Africa. Accessed on 10 ${ }^{\text {th }}$ December 2012 from http://www.educ.cam.ac.uk/centres/cce/ 
publications/eLearning_Africa_extended_overview Wamakote-1.pdf.

Ivers, K. S. (2003). A teacher's guide to using technology in the classroom. USA: California State University.

Jegede, P. \& Obafemi, other name?(2009). Assessment of Nigerian teacher educators' ICT training. Issues in Informing Science and Information Technology, 6, 2009.

Kenya Republic of. (1998). Sessional Paper No. 6 of 1988. Nairobi: Government Printer . (1968). Laws of Kenya: The Education Act. Nairobi: Government Printer.

Kilemi, M. \& Wamahiu, S. (1995). Issues in educational research in Africa. Nairobi: East African Educational Publishers.

Kimutai, G., \& Patrick, A. (2011). The role of human resource development in the realization of Kenya's Vision 2030. Paper presented at Kabarak University First International Conference, October 2011. Accessed on 20 th March, 2013 from http:// www.kabarak.ac.ke/downloads/sbiz/THE\% 20ROLE\%20OF\%20HUMAN\%20RES OURCE\% 20 D E V E L O P M E N T \% 20 I N \% 20 T H E \% 20REALIZATION\%20OF\%20KENYA\%20By\% 20Kimutai\%20G.\%20and\%20A\%20Patrick.pdf. 
Little, A. W. Hoppers \& R. Gardner. (1994). (eds.). Beyond Jomtien: Primary education for all in developing countries. London: Macmillan.

MOE. (2005). Sessional paper number 1 of 2005: A policy framework for education, training and research. Nairobi: Government Printer.. (2006). National ICT strategy for education and training. Nairobi: Government Printer.. (2009). Education facts and figures. Nairobi: Government Printer.

MOEST. (2005). Kenya ICT education and option paper of 2005. Nairobi: Government Printer. (2005). Kenya education sector support programme: Delivering quality equitable education and training to all Kenyans. Nairobi: Government Printer.

Ministry of Labour. (2012). Strategic Plan 2008 - 2012. Ministry of Labour, Social Security House: Nairobi.

Muyaka, J. (2012). 'Implementation of government ICT policies on teaching and learning in primary teachers colleges in Kenya: A comparative perspective'. Unpublished M. Ed Thesis, Kenyatta University.

Nduati, C., \& Bowman, W. (2005). "Working from the sidelines: the Kenya private sector foundation ICT board story." In E. F. Etta \& L. Elder (eds.), At the crossroads: ICT policy making in East Africa, 5667. Nairobi: East African Educational Publishers. 
Orodho, A. (2008). Techniques of Writing Research Proposals and Reports in Education and Social Sciences. Maseno: Kanezja Publishers.

Swarts, $P$ \& Wachira, E. (2010). Tanzania: ICT in Education Situational Analysis. Global Schools and Community Initiative, Tanzania. Retrieved on $10^{\text {th }}$ March, 2013 from http://www.gesci.org/assets/files/ Knowledge\%20Centre/Situational\%20Analysis Tanzania.pdf.

MOEST (2011). Tivet Institutions Kenya. TIVET ICT Baseline Survey Report. Nairobi: Government Printer.

UNESCO. (2002). UNESCO Report: Information and Communication Technologies in Teacher Education. Planning Guide. UNESCO. Accessed on $8^{\text {th }}$ March 2013 from: http://www.unesco.org . (2004). ICT pedagogy: UNESCO Office. France: Paris. . (2005). Global monitoring reports. France: Paris Accessed on 21st March 2013 from http://www.unesco.org/ education/GMR/2007/Full_report.pdf.

. (2006). Global monitoring reports. France: Paris Accessed on 21 ${ }^{\text {st }}$ March 2013 from http:// www.unesco.org/education/GMR/2007/ Full_report.pdf.

. (2007). Global monitoring reports. France: Paris. Accessed on 21 ${ }^{\text {st }}$ March 2013 from http://www.unesco.org/education/GMR/2007/ Full_report.pdf. 
. (2008). ICT competency standards for teachers.

United Kingdom: Metia Trucano M. (2013a)

ICTS and the education millennium development Goals (MDGs) Retrieved on $13^{\text {th }}$ March

2013 from http://www.infodev.org/en/ publication.140.html.

. (2013b). Using ICT in education to meet the millennium development goals Retrieved on $13^{\text {th }}$ March 2013 from http: www.infodev.org/ education.

Venezky, R. (2004). Technology in the classroom: Steps toward a new vision in education. Communication and Information, 4, 3-21.

Vision 2030. (2007). A Globally Competitive and Prosperous Kenya. Accessed on 21 $1^{\text {st Mar- }}$ ch2013fromhttp://www.google.co.ke/search? $\mathrm{q}=$ kenya + vision $+2030+$ download \&ie $=u t f-$ $8 \&$ oe $=$ utf $-8 \&$ a $=$ t $\&$ rls $=$ org.mozilla:en US:official\&client=firefox-a.

Wabuyele, L. (2003). Understanding teachers and administrators perceptions and experiences toward computer use in Kenyan classrooms: A case study of two schools. Athens: Ohio University.

Yin, R. (1984). Case study research: Design and methods, $1^{\text {st }}$ ed. Beverly Hills, CA: Sage. 